s

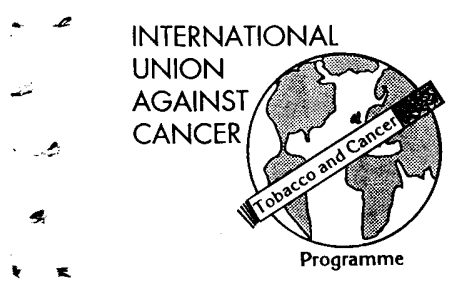

27

$r$

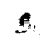

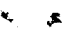

E.

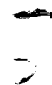

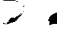

$+$

4

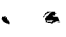

7

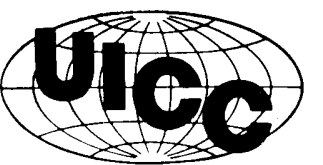

For further information contact: Mrs Isabel Mortara, Head, Education Department, 3 rue du Conseil-Général, 1205 Geneva, Switzerland. ( $\mathrm{Te}$ (41 22) 3201811 ; fax (41 22) 320 1810.)

Department of Cancer Control and Epidemiology, Marie Sklodowska Marie Sklodowsk
Curie Memorial Cancer Centre and Institute of Oncology, Warsaw, Poland Witold Zatoński

International Union Against Cancer Programme on Tobacco in Europe, Geneva, Switzerland

\title{
UICC international "No-Smoking Day" in central and eastern Europe, 19 November 1992
}

\author{
Witold Zatoński, Michael Wood
}

Central and eastern European countries have been characterised by deteriorating health since the mid-1960s, especially of the male population. The incidence of premature death in middle-aged men increased in Poland from 1965 to 1985 . Epidemiological estimates show that the main reason is the spreading epidemic of tobacco smoking. It is estimated that in the early 1990s every second premature death of middle-aged men in Poland was caused by tobacco smoking. The only realistic way to stop this epidemic is tobacco control.

Immediately after the new democracies returned to East Europe again, the UICC organised a conference "Tobacco-Free New Europe" in Kazimierz, Poland, in November, 1990. At this conference the strategy for tobacco control was established for the countries involved. In addition, one of the conference's recommendations was to encourage all smokers to quit.

The UICC, in cooperation with the American Cancer Society (ACS) organised campaigns modelled on the Great American Smokeout in Poland and Moscow, Russia, in 1990. These pilot-scale campaigns were intended to show whether the organisation of such events in eastern and central Europe is possible and what is their impact.

The pilot campaigns were very successful. The one organised in Poland, together with a popular evening daily Express Wieczorny and mottoed "Quit \& Win" competition, resulted in the reception of several thousand letters and had excellent publicity. The winner of a lottery, Mrs Anna Gronkowska, went for a trip to the USA which was organised together with the ACS, where she took part in the celebration of the Great American Smokeout in 1991 and was received at a special audience by Senator Edward Kennedy.

With the successful pilot campaign, the UICC began the preparation of a Smokeout in the entire central-eastern European region in 1992. It was held at the same time as the Great American Smokeout on 19 November 1992. UICC organised a coordinating meeting in Moscow, in June 1992, with the participation of ACS and representatives of the organisers of the British No-Smoking Day.

The campaigns were successful in most of the countries: Albania, Bulgaria, the Czech Republic, Estonia, Latvia, Lithuania, Poland, Russia, Slovakia, and Slovenia.

Albania - The National Directorate of Health Education carried out a number of activities: features about smoking on national radio every morning for the week of the campaign; stopsmoking courses offered to the general public at the Palace of International Culture in Tirana; a special television programme featuring medical experts discussing smoking; seminars in the hospitals to motivate and train medical personnel in smoking cessation techniques, and production and distribution of publicity and educational material throughout the country.

Bulgaria-The "No-Smoking Day" was celebrated with a number of activities, many of which were given media coverage by national television, radio and newspapers. Health promotion materials were distributed around the country and a series of lectures was given about smoking.

Czech Republic - Activities were coordinated by the National Health Promotion Centre in Prague in collaboration with the TB and Pneumology Clinic at Kutna Hora and included: a letter to all doctors in the Republic with leaflets about how to stop smoking; two smoking cessation training courses for therapists, in which more than 30 people took part; nicotine replacement therapy courses for smokers in Prague and Kutna Hora; and a press conference with a spokeswoman for the Minister of Health who discussed all aspects of tobacco control in the Republic. An important meeting of the Charles University Medical Faculty was televised.

A telephone "hot line" was launched for smokers wishing to stop. Two surveys were carried out to ascertain the prevalence of smoking and public awareness of the "NoSmoking Day". They showed that overall public awareness of the campaign was high $69 \%$ of respondents had heard about the event while $36 \%$ of smokers said they had cut down or given up for the whole day.

Estonia - The day was observed with 40000 special envelopes carrying the stop-smoking message being used at all post offices; special "No-Smoking Day" leaflets distributed in all trams and trolley buses; anti-smoking advertisements and advice on how to stop smoking in national and local newspapers; a televised debate on smoking with doctors and organisers of the campaign and a programme about smoking by medical students; inauguration of a twice weekly "stop-smoking" radio programme; four performances of the musical "Kiss me, Kate" in the Tallinn City concert Hall with a special exhibition and advice stall 
in the foyer; exhibitions on smoking in the Museum of Health Care and the Medical Library, and an art competition for schoolchildren.

Latvia - Latvian television, radio and newspapers all supported the "No-Smoking Day" campaign. Programmes on tobacco use were broadcast during the week and particularly on 19 November. One of the publicity activities featured on television took place at a maternity hospital and showed babies born that day wearing the "I'm a Born Nonsmoker" Tshirts.

Lithuania - The Health Education Centre organised the national activities. It produced posters and leaflets on "How to stop smoking" and distributed them throughout Lithuania. The Cancer Research Centre issued a statement which was broadcast on radio. A series of articles was published in several national newspapers and included interviews with health professionals an politicians. Advice on how to stop smoking was broadcast on national television and radio.

In Kaunas, the main event was the "Quit \& Win" competition organised jointly by the Health Research Centre, Kaunas Union Against Cancer, and the Health Education House, with a trip to Rome as the first prize. Entry forms were distributed in pharmacies and through the two main newspapers. A television crew filmed the ceremony of people swearing not to smoke, which took place in a smoke-free pedestrian precinct.

Poland - The "Great Polish Smokeout" was a tremendous success with over one million smokers actually trying to give up smoking and another four million smokers declaring that they wanted to stop smoking. The organisers concentrated their efforts on getting as much publicity as possible and their research showed that $90 \%$ of Polish people were aware of the campaign.

The major activity was the second national "Quit \& Win" competition, which attracted over 20000 entrants who all undertook to stop smoking for good. Many top Polish politicians, journalists and actors publicly declared that they quit smoking on that day. The leader of the Liberal Democratic Congress, Donald Tusk, also publicly said quitting was his biggest success in 1992.

Russia-The Russian campaign for "NoSmoking Day" was a collaboration between the Russian Cancer Society, the Cancer Research Centre, the Preventive Medicine Centre, the Ministry of Health, and the Moscow Health Centre. Organisers secured the involvement of three television channels, four radio stations and nine newspapers. One of the most popular events was a national radio programme lasting most of the day called "Youth", which included a "phone-in" for smokers to ask advice on how to stop.

In Moscow, nearly 80 schools took part in competitions, performances, exhibitions and lectures. In addition, schoolchildren were given two different leaflets - one for themselves on why smoking is bad and one for smokers in their family on how to stop smoking. The second leaflet was also distributed by the post office to more than 10000 Moscow homes.

Thirty clinics around Moscow offered help to over 4000 people who wanted to quit smoking. Media events included the award of "I'm a Born Nonsmoker" T-shirts to all babies born on 19 November in three maternity hospitals, along with a special booklet on smoking for the mothers.

Slovak Republic - A very popular children's television programme called on all Slovakian youngsters to help their parents to stop smoking on "No-Smoking Day". The ones who succeeded were awarded prizes. Another event was a national art competition on the theme of smoking.

During the week of the campaign, Dr Richard Peto visited Bratislava giving added publicity to the event. He addressed a major press conference and was received by the Vice Premier of the Slovak government, Dr Roman Kovac, who announced details of the latest measures to combat the smoking epidemic. These include a ban on advertising and a tax on all tobacco sales to help fund health promotion campaigns. The campaign was coordinated by the National Cancer Institute, the League Against Cancer, and the Cancer Research Institute.

Slovenia - An hour-long national radio debate on smoking was aired with the participation of the Minister for Health and a representative from the Traffic and Communications Ministry. Their discussion focused on the relations between smokers and non-smokers and the move to smoke-free public transport. Another major activity was an exhibition of the winning posters from a school art competition. National Slovene radio covered the exhibition and interviewed the schoolchildren.

The No-Smoking Day held in central and eastern Europe on 19 November 1992 was a complete success. It was not only reflected in national mass media but was also the topic of an article published by Newsweek. This campaign, in addition to the WHO-organised campaign on 31 May, became a permanent component of tobacco control activities in this part of Europe. 